Part 2.

Studia Iuridica Lublinensia vol. XXVII, 1, 2018

DOI: $10.17951 /$ sil.2018.27.1.75

Eric J. Segall

Georgia State University, Atlanta, USA

esegall@gsu.edu

\title{
To Overrule or Not? Precedent and the United States Supreme Court
}

\author{
Przełamać czy nie? Precedens i Sąd Najwyższy \\ Stanów Zjednoczonych
}

\section{SUMMARY}

The principle of stare decisis in United States courts appears in two aspects - the courts of lower jurisdiction are bound by the rulings issued by the courts of higher jurisdictions and as a horizontal binding of the Supreme Court by its own rulings. The latter 'binding' is not as strong as the former one, which is reflected in the Supreme Court judges' opinions and actions, which consist in both overruling their own precedents and highlighting the need for maintaining them. The changes of the Justices' attitudes leads to a negative answer to the question whether precedent - which is binding only when the Supreme Court's justices want it to be to be so - is binding precedent at all.

Keywords: precedent; stare decisis; overruling; U.S. Supreme Court

The phrase stare decisis literally means, "to stand by that which is decided". In the United States judicial system, there are two different aspects of stare decisis. First, lower courts in both the state and federal systems are required to follow the decisions of higher courts. For example, federal trial courts and federal courts of appeals must follow Supreme Court precedent whether or not the judges on the lower courts agree with those decisions. Lawyers and judges call this kind of duty vertical stare decisis. Although there is little reliable data on the subject, most federal judges take this obligation seriously and do not issue decisions inconsistent with Supreme Court precedent.

The second type of precedent is horizontal stare decisis. The Supreme Court is supposed to take its own prior case law seriously and not overturn its own decisions absent a strong reason for doing so. However, the Justices have been less than consistent in describing this duty. On the one hand, they have said that the rule 
of stare decisis is of "fundamental importance to the rule of law", furthering "the evenhanded, predictable, and consistent development of legal principles", and contributing to "the actual and perceived integrity of the judicial process". The Court has also said that precedent should normally be followed because "in most matters, it is more important that the applicable law be settled than it be settled right"2.

On the other hand, the Justices have often said that its duty to follow their own prior decisions is not "an inexorable command" interpretation, where the Congress can overturn an incorrect Court decision, the Justices are likely to be more reluctant to overturn cases than in constitutional matters where "correction through legislative action is practically impossible"4. A Court majority has said on numerous occasions that when a prior case is either unworkable or even badly reasoned, the Justices have "never felt constrained to follow precedent"s.

In fact, it turns out that in constitutional cases, the Justices have failed to articulate a coherent philosophy defining their duty to follow their own decisions. One commentator has remarked, "the modern doctrine of stare decisis is essentially indeterminate. The various factors that drive the doctrine are largely devoid of independent meaning or predictive force. Fairly or not, this weakness exposes the Court to criticism for appearing results-oriented in its application of stare decisis" From 1960-2009, according to one study ${ }^{7}$, the Court reversed roughly 75 of its own cases while at the same time often discussing in other cases the importance of rule of law values gained by following prior decisions.

The hardest question concerning the role stare decisis plays in Supreme Court decision-making is whether the doctrine really matters at all. When the Justices affirm a prior decision that they approve of, precedent does little work. The perplexing issue is how often do the Justices follow case law that they believe to be erroneous. In light of the fact, demonstrated below, that the Court has dramatically changed positions in virtually every litigated area of constitutional, the answer is likely that stare decisis, contrary to popular myths, does almost no work in Supreme Court constitutional cases ${ }^{8}$.

${ }^{1}$ See: R. Kozel, Stare Decisis as Judicial Doctrine, "Washington \& Lee Law Review" 2010, No. 67, pp. 411-412 (quoting various Supreme Court decisions).

2 Burnett v. Colorado Oil \& Gas Company, 285 U.S., 393, 406-407 (1932).

${ }^{3}$ R. Kozel, op. cit., p. 414, quoting Payne v. Tennessee, 501 U.S. 808, 828 (1991).

${ }^{4}$ Burnett, 285 U.S. at 407.

${ }^{5}$ Smith v. Allright, 321 U.S. 649, 665 (1944).

${ }^{6}$ R. Kozel, op. cit., p. 414.

7 See: R. Standler, Overruled: Stare Decisis in the U.S. Supreme Court, www.rbs2.com/overrule. pdfhttp://www.rbs2.com/overrule.pdf [access: 10.02.2018].

${ }^{8}$ This paper does not address the Justices use of precedent in statutory interpretation cases. 
It would take a book to describe all the areas of constitutional law where the Supreme Court has fundamentally altered its own prior doctrine. Nevertheless, the examples below should suffice to make the point. At one time, the Justices deemed commercial speech simply proposing economic transactions to be completely outside the scope of the First Amendment, but now the Court fully protects such speech ${ }^{9}$. At one time, the Justices held that the government could provide no aid other than secular textbooks to religious schools because the Establishment Clause forbid that use of tax dollars, but now the Court permits virtually all aid if the materials, supplies, or vouchers are also provided to children in non-religious schools. In addition, under the first amendment, the Court once held that schools could require children to say the pledge of allegiance, but just a few years later, reversed that decision ${ }^{10}$.

In 1871, in a landmark decision, the Supreme Court held that Congress did not have the legal authority to issue paper money because the Constitution only mentions "Coin". Just a year later, after President Ulysses S. Grant, made two appointments to the Court, both of whom were known to be in favor of federal authority to make paper money legal tender, the Justices reversed their decision and approved that authority even though the only thing that had changed during that year was the composition of the Court ${ }^{11}$. A newspaper at the time said that the second decision "is generally regarded not as the solemn adjudication of an upright and impartial tribunal, but as a base compliance with Executive instructions by creatures of the President placed upon the Bench to carry out his instructions"12.

From 1791-2007, the Supreme Court had never interpreted the Second Amendment, which provides that "A well-regulated militia, being necessary to the security of a free state, the right of the people to keep and bear arms shall not be infringed", to confer on individuals a personal right to own guns. In 1935, the Court in United States v. Miller interpreted that text to apply only to those arms that bear a "reasonable relationship to the preservation or efficiency of a well-regulated militia"13. Yet, in 2008, in a five-to-four opinion, the Court held exactly the opposite in District of Columbia v. Heller ${ }^{14}$, finding that people have a constitutional right to bear arms in the home for self-defense providing those arms are in "common use".

9 See: Public Funding for Religious Schools, www.pewforum.org/2009/05/14/shifting-boundaries5 [access: 10.02.2018].

10 West Virginia State Board of Education v. Barnette, 319 U.S. 624 (1943).

${ }^{11}$ See: www.thegoldstandardnow.org/the-legal-tender-cases [access: 10.02.2018].

12 S. Ratner, Was the Supreme Court Packed by President Grant?, "Political Science Quarterly" 1935, No. 50, pp. 343, 347-348 (quoting Ch. Warren, The Supreme Court in United States History, Boston 1926, pp. 525-526).

${ }^{13}$ United States v. Miller, 307 U.S. 174, 178 (1939).

${ }^{14}$ District of Columbia v. Heller, 554 U.S. 570 (2008). 
An issue that the Court has changed its mind on numerous times is whether Congress may require state governments to perform federally specified tasks when Congress exercises enumerated powers. In 1936, the Court said that Congress could regulate California's state-owned railroad without regard to state sovereignty ${ }^{15}$. The Court stated clearly that the "power of a state to fix intrastate railroad rates must yield to the power of the national government when their regulation is appropriate to the regulation of interstate commerce" ${ }^{16}$. In other words, when Congress enacts legislation pursuant to its enumerated powers, states may not object to that regulation on the basis of state sovereignty.

This ruling remained in effect until 1976 when the Court held in National League of Cities v. Usery ${ }^{17}$, that Congress could not regulate a state's traditional governmental functions. Then, in 1985, the Court reversed course again in Garcia v. San Antonio Transit Authority ${ }^{18}$, when the Justices explicitly reversed Usery. The Court once again said that state sovereignty does not trump Congress' enumerated powers. Once again, Congress could commandeer the states and make them do federal bidding.

Garcia, however, also did not last. Once Justice Clarence Thomas changed the balance of the Court in 1991, the Justices reversed course yet again. In two cases, the conservatives on the Court created an anti-commandeering principle that even when Congress exercises powers under Article I, it may not require states to assist in the implementation of federal law, unless the law also applies to private actors as well ${ }^{19}$.

A few years later, the Court cast some doubt on this doctrine, holding that Congress could dictate conditions to state-operated motor vehicle departments when they wanted to sell their citizens' drivers' license information despite the state's anti-commandeering argument ${ }^{20}$. This history of holdings, counter-holdings, and then counter-counter holdings from 1937 to today shows clearly that the Justices are more than willing to make a mockery of the idea of stare decisis.

There are many other important areas of constitutional law where the Justices have reversed prior decisions for no other reason than the Justices possessed differ-

15 U.S. v. California, 297 U.S. 175 at 183-185 (1936).

16 U.S. v. California, 297 U.S. 175 at 184.

17 National League of Cities v. Usery, 426 U.S. 833 (1976).

18 Garcia v. San Antonio Transit Authority, 469 U.S. 528 (1985).

19 New York v. U.S., 505 U.S. 144 at 149 (1992) (“[W]hile Congress has substantial power under the Constitution to encourage the States to provide for the disposal of the radioactive waste generated within their borders, the Constitution does not confer upon Congress the ability simply to compel the States to do so"); Printz v. United States, 521 U.S. 898 at 935 (1997) ("Congress cannot circumvent [the rule of New York] by conscripting the State's officers directly. The Federal Government may neither issue directives requiring the States to address particular problems, nor command the States' officers, or those of their political subdivisions, to administer or enforce a federal regulatory program").

${ }^{20}$ Reno v. Condon, 528 U.S. 141 at 149-151 (2000). 
ent values than the ones who decided the prior case or doctrine. The Justices have changed their minds on whether sovereign immunity bars lawsuits against a state by citizens of that $\operatorname{state}^{21}$; on whether states can impose the death penalty on the mentally ill and juveniles under the age of $18^{22}$; and on whether corporations have the same freedom of speech rights as people ${ }^{23}$. In sum, the Court has issued major reversals in the areas of freedom of speech, separation of church and state, gun rights, the death penalty, federalism, and a myriad of other individual rights claims.

The Supreme Court of the United States is a hybrid legal-political institution. The Justices are the only highest court judges in the free world who hold their offices for life. They are often asked to interpret vague constitutional and statutory text with contested historical accounts of why the drafters enacted that tex $\mathrm{t}^{24}$. The myth that prior cases matter to the Justices is one of the ways the American people keep faith in this unique governmental institution. However, as this paper has shown, the Justices reverse themselves on a regular basis and often for no other reason than the people who serve as Justices have changed, and so have the values of the Institution. If precedent only matters when the Justices want it to, does it really matter at all? Sadly, the answer appears to be no.

\section{REFERENCES}

https://deathpenaltyinfo.org/u-s-supreme-court-roper-v-simmons-no-03-633 [access: 15.02.2018].

Kozel R., Stare Decisis as Judicial Doctrine, "Washington \& Lee Law Review" 2010, No. 67.

Public Funding for Religious Schools, www.pewforum.org/2009/05/14/shifting-boundaries5 [access: 10.02.2018].

Ratner S., Was the Supreme Court Packed by President Grant?, "Political Science Quarterly" 1935, No. 50 .

Segall E., Supreme Myths. Why the Supreme Court is Not a Court and Its Justices Are Not Judges, Santa Barbara-Denver-Oxford 2012.

Standler R., Overruled: Stare Decisis in the U.S. Supreme Court, www.rbs2.com/overrule.pdfhttp:// www.rbs2.com/overrule.pdf [access: 10.02.2018].

Warren C., The Supreme Court in United States History, Boston 1926.

www.thegoldstandardnow.org/the-legal-tender-cases [access: 10.02.2018].

${ }^{21}$ Seminole Tribe v. Florida, 517 U.S. 44 (1996).

${ }^{22}$ See: https://deathpenaltyinfo.org/u-s-supreme-court-roper-v-simmons-no-03-633 [access: 15.02.2018].

${ }^{23}$ Citizens United v. Federal Election Commission, 558 U.S. 310 (2010).

${ }^{24}$ See: E. Segall, Supreme Myths. Why the Supreme Court is Not a Court and Its Justices Are Not Judges, Santa Barbara-Denver-Oxford 2012. 
Pobrane z czasopisma Studia Iuridica Lublinensia http://studiaiuridica.umes.pl

Data: 26/04/2023 17:25:11

\section{STRESZCZENIE}

Formuła stare decisis w porządku common law występuje w dwóch aspektach - jako związanie sądów niższych orzeczeniami sądów wyższych oraz jako horyzontalne związanie Sądu Najwyższego własnymi decyzjami. To drugie „związanie” nie jest tak mocne, jak to pierwsze, co przejawia się w przekonaniach i działaniach sędziów tego sądu, które polegają tak na przełamywaniu swoich precedensów, jak i na podkreślaniu potrzeby ich podtrzymywania. Dają się zauważyć w tym kontekście zmiany stanowiska sądu w różnych okresach jego funkcjonowania, co prowadzi jednak do negatywnej odpowiedzi na pytanie, czy precedens, który wiąże jedynie wówczas, gdy chcą tego sędziowie Sądu Najwyższego, jest w ogóle precedensem wiążącym.

Słowa kluczowe: precedens; stare decisis; przełamanie; Sąd Najwyższy Stanów Zjednocznych 